\title{
Perceived Stress Level and Sports Participation in Deaf Adolescents and Young Adults
}

\author{
Sehmus Aslan \\ Correspondence: Faculty of Sport Sciences, Pamukkale University, Denizli, Turkey. \\ Received: January 16, 2019 \\ Accepted: February 21, 2019 Online Published: February 26, 2019 \\ doi:10.11114/jets.v7i3.3974 \\ URL: https://doi.org/10.11114/jets.v7i3.3974
}

\begin{abstract}
The aim of this study is to investigate the effect of sports participation on perceived stress level in deaf adolescents and young adults. A total of 110 deaf people aged between 14 and 25 years participated in the study. The Turkish version of the Perceived Stress Scale (PSS) was used to assess perceived stress level of the participants. The scale is a 5-item Likert scale and 10-item scale. The scores of PSS-10 consist of 0-40.

$44(40.0 \%)$ of the participants were female and $66(60.0 \%)$ were male. The mean age of female participants were 16,66 $\pm 1,36$ years and male participants were 17,74 $\pm 1,65$ years. Of the participants, $85(77.3 \%)$ had antenatal and 25 (22.7\%) had post-partum hearing impairment. Of the participants, 67 (60.9\%) did participate sports and $43(39.1 \%)$ did not participate in sports. No statistically significant difference was found in terms of sex, hearing disability level and having congenital or acquired disability ( $p>0.05$ ). The total score of PSS of the athletes were 22,33 $\pm 6,33$ and the total score of the non-athletes were $26,74 \pm 3,46$. There was a statistically significant difference between the groups $(\mathrm{p}<0.05)$. However, no statistically significant difference was found in terms of gender, the grades of hearing disability, and having congenital or acquired disability $(p>0.05)$. The results of our study showed that the perceived stress levels of deaf adolescents and young adults who participate in sports were lower than compared who did not participate in sports. This study demonstrated sports participation might recommend to adolescents and young adults with hearing impairment for reducing stress.
\end{abstract}

Keywords: hearing impairment, stress, sport, participation

\section{Introduction}

Stress is the biochemical response of the body to a threatening condition in causing stress (Ellison, 1990; Sanl1, 2017). The negative feelings and beliefs that people experience when they feel due to cannot cope with the demands of their environment can be described as stress (Aronson-Wilson et al. 2012). Cüceloğlu (2011) defines stress as "an effort that the individual puts beyond his / her physical and psychological boundaries due to the discordant conditions in the physical and social environment" (Cüceloğlu, 2011). Today, stress has become an important part of modern life and a factor that can affect all aspects of human life. Stress has a negative effect on the daily normal functioning of a person, and prolonged exposure to stress leads to the emergence of various health problems, and even affects the functioning and quality of life negatively (Eskin et al., 2013).

Stress is not only about adults (Wible, 2013), Children and adolescents can experience stress just like adults. This stress of children and adolescents can be caused by various situations such as achieving academic success, making and maintaining friends, and managing the expectations of their parents and teachers (APA 2009; Oral and Ersan, 2017). Stress affects the well-being of a person, decreasing his capacity and making compelling effects (Ünal and Ümmet, 2005). In this context, it is known that disabled students face many problems that exceed their physical and psychological boundaries and thus force their capacity (Savc1 and Aysan, 2014).

Hearing disability is a common problem in the world and the World Health Organization has reported that there are 360 million people with hearing loss worldwide. Hearing impairment; partial or total hearing loss due to the use of verbal language in daily life as a functional condition. Speech and language delays and communication problems of deaf individuals cause negatively affect the life of the individual (Aslan Bas and Aslan, 2017).

Deaf people do not have equal social and cultural facilities due to their sensory loss. One of the main reasons for this is that they prefer to communicate with each other in particular and often avoiding interacting with other individuals in the society. Regular sports and physical activity is important to maintain the health and well-being of people of all ages. 
Sports and physical activities provided during childhood starting from pre-school period are also an important activity for the disabled people. Sports is applied for the integration of people with disabilities in the society and rehabilitation. Sports participation is also to increase the quality of life of people with disabilities (Gür, 2001; Şirinkan, 2011).

In hearing people, physical activity provides a state of well-being that enables individuals to realize their own potential, and that helps to cope with the normal stresses of life or adversity (Poirel, 2017). The aim of this study is to investigate the effect of sports participation on perceived stress level in groups?

\section{Method}

The study included 110 deaf participants. The mean age of the participants were $18,79 \pm 3,11$ years for athletes and $16.70 \pm 1,97$ years for non-athletes.

Table 1. Sports participation distribution

\begin{tabular}{cll}
\hline Participation in sports & $\mathrm{n}$ & $\%$ \\
\hline Yes & 67 & 60,9 \\
No & 43 & 39,1 \\
\hline Total & 110 & 100,0 \\
\hline
\end{tabular}

As seen in Table 1, 67 (60.9\%) participants were athletes and 43 (39.1\%) were non-athletes (Table 1).

Table 2. Distribution of sports branches

\begin{tabular}{lll}
\hline Sport & $\mathbf{n}$ & $\mathbf{\%}$ \\
\hline Basketball & 38 & 34,5 \\
Soccer & 24 & 21,8 \\
Table tennis & 5 & 4,5 \\
\hline Total & 67 & 60,9
\end{tabular}

When the sports branch of the participants were examined, 38 participants (34.5\%) basketball, 24 participants (21.8) soccer and 5 participants (4.5\%) table tennis (Table 2).

Table 3. Gender distribution of the sample

\begin{tabular}{l|lcccccc}
\hline \multirow{2}{*}{ Female } & \multicolumn{2}{|c}{ Participate in sport } & \multicolumn{2}{c}{ Non-sport } & \multicolumn{2}{c}{ Total } \\
\multirow{2}{*}{ Male } & $\mathbf{n}$ & $\boldsymbol{\%}$ & $\mathbf{n}$ & $\boldsymbol{\%}$ & $\mathbf{n}$ & $\boldsymbol{\%}$ \\
\cline { 2 - 7 } & 24 & 35.8 & 20 & 46.5 & 44 & 40 \\
& 43 & 64.2 & 23 & 53.5 & 66 & 60 \\
\hline
\end{tabular}

$35.8 \%(\mathrm{n}=24)$ of the athletes were female and $64.2 \%(\mathrm{n}=43)$ were male. Of those who did not participate in sport, $46.5 \%$ $(\mathrm{n}=20)$ were female and $53.5 \%(\mathrm{n}=23)$ were male (Table 3$)$.

Table 4. Occurrence of the hearing impairment

\begin{tabular}{l|lcccccc}
\hline & \multicolumn{2}{|c}{ Participate in sport } & \multicolumn{2}{c}{ Non-sport } & \multicolumn{2}{c}{ Total } \\
& $\mathbf{n}$ & $\%$ & n & \% & n & \% \\
\cline { 2 - 7 } Congenital & 52 & 77.6 & 33 & 76.7 & 85 & 77.3 \\
Acquired & 15 & 22.4 & 10 & 23.3 & 25 & 22.7 \\
\hline
\end{tabular}

$77.3 \%(\mathrm{n}=85)$ of the participants had congenital and, $22.4 \%(\mathrm{n}=15)$ of the participants had acquired hearing impairments (disease etc.) (Table 4).

Table 5. Distribution of participants' grades of hearing impairment

\begin{tabular}{l|llrlll}
\hline & \multicolumn{2}{l}{ Participate in sport } & \multicolumn{2}{c}{ Non-sport } & \multicolumn{2}{l}{ Total } \\
Moderate & $\mathbf{n}$ & $\mathbf{\%}$ & $\mathbf{n}$ & $\mathbf{\%}$ & n & \% \\
\cline { 2 - 7 } Moderately severe & 26 & 38.8 & 15 & 34.9 & 41 & 37.3 \\
Severe & 21 & 31.3 & 7 & 16.3 & 28 & 25.5 \\
\hline
\end{tabular}

$38.8 \%(\mathrm{n}=26)$ of the participants who participate in sport had moderate, $31.3 \%(\mathrm{n}=21)$ moderately severe and $29.9 \%(\mathrm{n}$ $=20)$ severe hearing impaired. $34.9 \%(n=15)$ of the non- athlete participants had moderate, $16.3 \%(n=7)$ moderately severe and $48.8 \%(\mathrm{n}=21)$ severe hearing impairment (Table 5). 


\section{Data Collection Tools}

The sample of the study consisted of 110 volunteer hearing-impaired students and club players aged between 14-25 years, who were studying at Ibrahim Cengiz Private Education Vocational High School and playing in sports clubs in Denizli in 2016-2017 academic year.

\section{Short Version of the Perceived Stress Scale (PSS)}

As a data collection tool, the personal information form and the short version of the Perceived Stress Scale (PSS) was used which was developed by Cohen, Kamarck and Mermelstein (1983). The Turkish language adaptation of the scale was done by Eskin et al. (2013). The scale consists of 5 Likert type and 10 items. The scores of PSS-10 are between 0-40. A high score indicates a high level of stress perception. The score of the scale was never: 0 points, almost no: 1 point, sometimes: 2 points, frequently: 3 points, very often: 4 points (Cohen and Kamarck 1983; Eskin, 2013).

\section{Analysis of Data}

SPSS 22.00 package program was used to analyze the data obtained from the study. Descriptive statistics, t-test and One Way ANOVA test were used for statistical analysis. For this study, Cronbach Alpha reliability coefficient of the scale was 0.78 ( $\mathrm{p}=0,000$ ).

\section{Results}

The statistical analyses according to determinants in terms of sports participation, gender, disability, and hearing impairment are presented below.

Table 6. t-test results of the participants' gender

\begin{tabular}{l|lllllll}
\hline \multirow{3}{*}{ Total PSS score } & Gender & $\mathbf{n}$ & $\overline{\boldsymbol{x}}$ & Ss & $\mathbf{t}$ & $\mathbf{d f}$ & $\mathbf{p}$ \\
\cline { 2 - 8 } & Female & 44 & $24,39 \pm$ & 5,34 & & & \\
& Male & 66 & $23,83 \pm$ & 6,10 & 0,489 & 108 & 0,62 \\
\hline
\end{tabular}

$\mathrm{p}<0,05$

The mean PSS score of females were $24.39 \pm 5.34$ and the male participants were $23.83 \pm 6.10$. Although PSS scores of females were higher than males, there was no statistically significant difference between them (p <0.05) (Table 6).

Table 7. Comparison of PSS scores of participants according to occurrence of the hearing impairment

\begin{tabular}{|c|c|c|c|c|c|c|c|}
\hline & Disability & n & $\overline{\bar{x}}$ & Ss & t & df & $\mathbf{p}$ \\
\hline Total PSS score & $\begin{array}{l}\text { Congenital } \\
\text { Acquired }\end{array}$ & $\begin{array}{l}85 \\
25\end{array}$ & $\begin{array}{l}24,14 \pm \\
23,74 \pm\end{array}$ & $\begin{array}{l}5,81 \\
5,81\end{array}$ & 0,288 & 108 & 0,77 \\
\hline
\end{tabular}
$\mathrm{p}<0,05$

The mean PSS score of the participants with congenital hearing impairments were $24,14 \pm 5,81$ and the scores of the participants with acquired hearing impairments were $23,74 \pm 5,81$. There was no statistically significant difference between them $(\mathrm{p}<0.05)$ (Table 7).

Table 8. Comparison of PSS scores of participants according to hearing impairment.

\begin{tabular}{|c|c|c|c|c|c|c|c|}
\hline \multirow{5}{*}{ Total PSS score } & $\begin{array}{l}\text { Grade of hearing } \\
\text { impairment }\end{array}$ & $\mathbf{n}$ & $\overline{\boldsymbol{x}}$ & Ss & df & $\mathbf{F}$ & $\mathbf{p}$ \\
\hline & Moderate & 41 & $24,24 \pm$ & 4,78 & \multirow{4}{*}{2} & \multirow{3}{*}{0,129} & \multirow{3}{*}{0,87} \\
\hline & Moderately-severe & 28 & $23,57 \pm$ & 6,35 & & & \\
\hline & Severe & 41 & $24,20 \pm$ & 5,79 & & & \\
\hline & Total & 110 & & & & & \\
\hline
\end{tabular}

$\mathrm{p}<0,05$

The mean PSS scores of the moderate, moderately severe and severe deaf participants were 24,24 $\pm 4,78,23,57 \pm 6,35$ and $24,20 \pm 5,79$, respectively. There was no statistically significant difference in PSS scores according to the degree of hearing impairment grade $(\mathrm{p}<0.05)$ (Table 8).

Table 9. Comparison of PSS scores of participants according to sport participation

\begin{tabular}{|c|c|c|c|c|c|c|c|c|}
\hline \multirow[b]{4}{*}{$\begin{array}{l}\text { Total } \\
\text { score }\end{array}$} & \multirow[b]{4}{*}{ PSS } & \multicolumn{7}{|c|}{ Sport participation } \\
\hline & & & n & $\bar{x}$ & Ss & $\mathbf{t}$ & df & $\mathbf{p}$ \\
\hline & & Yes & 67 & $22,33 \pm$ & 6,33 & & & \\
\hline & & No & 43 & $26,74 \pm$ & 3,46 & $-4,185$ & 108 & 0,000 \\
\hline
\end{tabular}

The mean PSS score of the athlete participants were 22,33 $\pm 6,33$ and the score of the non-athlete participants is $26,74 \pm$ 3,46 . The PSS score of the athlete participants were higher than the score of the non-athlete participants. There was a statistically significant difference between them ( $p>0.05)$ (Table 9). 


\section{Discussion}

This study was carried out to investigate the effect of sports participation on perceived stress level in deaf adolescents and young adults. The perceived stress level of adolescents and young adults who participate in sport were lower than those who did not participate in sport. A similar result was found in study by Yorks et al. (2017) that assessed effect of group or individual exercise in hearing university students. The authors reported that 12 weeks of group fitness exercise showed a decrease in perceived and an increase in physical, mental, and emotional QOL compared with exercising regularly on one's own or not engaging in regular exercise (Yorks et al., 2017).

Özkatar, Kaya and Şanal (2011) compared the stress and aggression levels of deaf athletes and non-athletes. They found differences in the level of aggression between the athletes and non-athletes. And also, in their study it was reported that no difference between the athlete and non-athlete in terms of stress levels. On the other hand, our result is not similar. We found that the participants who participate sport have lower perceived stress level than those who did not participate sport. Conflict the results in the studies are due to the using different aspect of stress. In this study, perceived stress level was evaluated while in the study of Özkatar, Kaya and Şanal, was examined that the work stress and stress related sports satisfaction (Kaya Özkatar and Şanal, 2011).

In the literature, researches about deaf people is limited (Dursun et al., 2015) were evaluated with the effect of ice skating, psychological well-being, self-concept and sleep in 20 deaf and 20 visually impaired children aged 8-16 years. Their results showed that a significant improvement in deaf children by ice skating. Civan et al. (2011) compared the anxiety levels of deaf athletes and sedentary. They reported that the level of trait anxiety of the deaf people who exercise regularly is lower than those the sedentary.

Previous studies have emphasized the positive effects of sports in different disability groups. Participating in sports and physical activity protects the disabled person from the effects of the psychological discomfort and psychic tension caused by his disability. Furthermore, emphasized that people with disabilities engaged in sports are in better social relations in community life than in non-sports disabled people (Schüle, 1987; Karakoç, Çoban and Konar, 2012). Tiryaki et al. (2000) stated that disabled who participate in are more externally and emotionally balanced than sedentary disabled individuals. Participation in sport could also help coping with social anxiety. It has been determined that children participating in team sports have less social anxiety over time (Schumacher, Dimech and Seiler, 2011). Sport is one of the best methods of integrating people with disabilities into society. Nowadays, there are different sports opportunities for people with disabilities according to their status and level of disability. Sport also contributes more independent life to disabled individuals (O’Conne, 2000; Civan et. al., 2012).

In our study, the effect of the sports participation as well as gender, hearing impairment level and the having congenital or acquired disability on the level of perceived stress were investigated. The perceived stress levels of the women and men were similar. There was no difference between the stress levels of the participants with moderate, moderately severe and severe hearing impairment. The level of stress of the participants who had a congenital hearing and acquired was similar. Gürer et al. (2014) reported similar results with our study in their study, the stress levels of hearing and physical disability athletes were examined. As a result of the study, the relationship between the level of stress experienced by disabled athletes was not found to be related to gender, marital status, age, educational status, occupation, salary, occupational experience and reasons for disability. As a result, they reported that sports have a positive effect on stress regardless of their branches and obstacles (Gürer et al., 2014).

The results of this study showed that the perceived stress levels of deaf adolescents and young adults who participate in sports were lower than compared who did not participate in sports. Therefore, sports participation might recommended to adolescents and young adults with hearing impairment to reduce stress. In addition, as in other disability groups, hearing impaired people participate in less physical activity than healthy individuals ( $\mathrm{Li}$ and $\mathrm{Wu}, 2018$ ). Therefore, efforts should be made for deaf individuals to support their participation in sports.

\section{Acknowledgements}

The author is grateful to Ayşegül Öğünç for assisting in the data collection of this research.

\section{References}

American Psychological Association (APA). Stress in America. http://www.apa.org/news/press/releases/stress/2009/signs-stress.pdf [02.01.2019]. [24]

Aronson, E., Wılson, D. T., \& Akert, M. R. (2018). Sosyal Psikoloji, (çev. Okhan Gündüz), İstanbul, Kaknüs Yay. pp.864.

Aslan, B. U., \& Aslan, Ş. (2017). Spor Yapan ve Yapmayan İșitme Engelli Bireylerin Benlik Saygısının Karşılaş̧tırlması, "World Congress of Sport Sciences Researches", 23-26 November, Turkey.

Civan, A., Özdemir, İ., Taş, İ., \& Çelik, A. (2012). Bedensel Engelli ve Engelli Olmayan Tenis Sporcularının Durumluk ve Sürekli Kaygı Düzeylerinin Karşılaştırılması, Selçuk Üniversitesi Beden Eğitimi ve Spor Bilim Dergisi, 14(1), 
83-87.

Cohen, S., Kamarck, T., \& Melmerstein, R. (1983). A Global Measure of Perceived Stress, Journal of Health and Social Behavior, 24, 385-396. https://doi.org/10.2307/2136404

Cüceloğlu, D. (2011). Insan ve Davranışı, İstanbul, Remzi Kitabevi, 22, 321.

Dursun, O. B., Erhan, S. E., Ibiş, E. Ö., Esin, I. S., Keleş, S., Şirinkan, A., .. Beyhun, N. E. (2015). The effect of ice skating on psychological well-being and sleep quality of children with visual or hearing impairment, Disabil Rehabil. 37(9), 783-789. https://doi.org/10.3109/09638288.2014.942002

Ellison, L. (1990). “Managing Stress in Schools', in Davies, B., Ellison, L., Osborne, A. And West-Burnham, J. (eds.). Education Management for the 1990's. Harlow: Lognman.

Eskin, M., Harlak, H., Demirkıran, F., \& Dereboy, Ç. (2013). Algılanan Stres Ölçeğinin Türkçeye Uyarlanması: Güvenirlik ve Geçerlik Analizi, New Symposium Journal, 51(3), 132-140.

Gür, A. (2001). Özürlülerin Sosyal Yaşamda Uyum Süreçlerinde Sportif Etkinliklerin Rolü, T.C. Başbakanlık Özürlüler İdaresi Başkanlığı, Ankara.

Gürer, B., Kılınç, Z., Şahin, M. H., \& Esentaş, M. (2014). İşitme ve Bedensel Engelli Sporcuların Stres Düzeylerinin Bazı Demografik Değişkenler Yönünden İncelenmesi, Akademik Sosyal Araştırmalar Dergisi, 2(2/1), 352-359.

Karakoç, Ö., Çoban, B., \& Konar, N. (2012). İşitme Engelli Milli Sporcular ile Spor Yapmayan İşitme Engellilerin Benlik Saygısı Düzeylerinin Karşılaştırılması, Selçuk Üniversitesi Beden Eğitimi ve Spor Bilim Dergisi, 14(1), 12-17

Kaya Özakatar, E., \& Şanal, M. (2011). The Investigation of Stress and Aggression Levels in Hearing Impaired Sportsmen Aged Between 18-25 Years Old, Ovidius University Annals, Series, Physical Education and Sport / Sclence, Movement and Health Vol. 11, ISSUE 2, Romania 166,169,170.

Li, C., Haegele, J. A., \& Wu, L. (2018). Comparing physical activity and sedentary behavior levels between deaf and hearing adolescents. Disability and Health Journal, Available online 21 December 2018, https://doi.org/10.1016/j.dhjo.2018.12.002

O'Conne, U. M. (2000). The effect of brailling and physical guidance on the self-efficacy of children who are bIind, Unpublished master's thesis, State University of New York College at Brockport, NY.

Oral, T., \& Ersan, C. (2017). Çocuklarda (8-11 Yaş) Algılanan Stres Ölçeği’nin Türkçeye Uyarlama Çalışması, Selçuk University Journal of Faculty of Letters, (37), 419-428.

Poirel, E. (2017). Psychological benefits of physical activity for optimal mental health, Sante Ment Que, Spring, 42(1), 147-164.

Sanlı, Ö. (2017). Analysing The Perceived Stress Level of Teachers with Regards to Some Variables, Electronic Journal of Social Sciences ISSN: 1304-0278, 16(61), 385-396.

Savcı, M., \& Aysan, F. (2014).Üniversite Öğrencilerinde Algılanan Stres Düzeyi İle Stresle İle Başa çıkma Stratejileri Arasındaki İlişki, International Journal of Turkish Education Sciences, 3, 44-56.

Schüle, K. (1987). Effektiviaet und Effizienz in der Rehabilitation, Richarz Yayınevi, St. Augustin.

Schumacher, D. A., \& Seiler, R. (2011). Extra-curricular sport participation: A potential buffer against social anxiety symptoms in primary school children, Psychology of Sport and Exercise, 12(4), 347-354. https://doi.org/10.1016/j.psychsport.2011.03.007

Şirinkan, A. (2011). 10-15 Yaş İşitme Engelli Öğrencilerde Sportif Eğitsel Oyunların Fiziksel Gelişimlerine Etkisinin Araştırılması, Selçuk Üniversitesi Beden Eğitimi ve Spor Bilim Dergisi, 13. (Ek Sayı).

Tiryaki, Ş. (2000). Spor Psikolojisi Kavramlar, Kuramlar ve Uygulama. 1. Bask1, Eylül Yayınevi, 109. İstanbul.

Ünal, S., \& Ümmet, D. (2005). Örgütsel Stres Kaynakları ve Öğretmenlerin Baş Etme Stratejileri, Pamukkale Üniversitesi Yayınlart: Denizli.

Wible, C. (2013). Why You Should Fake a Smile: How Your Emotions Affect Your Student's Learning. http://www.opencolleges.edu.au/informed/features/contagious-emotions/ (02.01.2019).

Yorks, D. M., Frothingham, C. A., \& Schuenke, M. D. (2017). Effects of Group Fitness Classes on Stress and Quality of Life of Medical Students, J am Osteopath Assoc., 117(11), 17-25. https://doi.org/10.7556/jaoa.2017.140

\section{Copyrights}

Copyright for this article is retained by the author(s), with first publication rights granted to the journal.

This is an open-access article distributed under the terms and conditions of the Creative Commons Attribution license which permits unrestricted use, distribution, and reproduction in any medium, provided the original work is properly cited. 